Prabowo, S.M. • S.A. Dewi

\title{
Ekstrak daun bunga pukul empat dan daun pagoda sebagai tanaman antivirus untuk mengendalikan penyakit keriting pada cabai rawit (Capsicum frutescens L.)
}

\section{The leaves extract of four o'clock flower and pagoda as antivirus plants to control curl disease on cayenne pepper (Capsicum frutescens $\mathrm{L}$.)}

\author{
Diterima : 13 Desember 2018/Disetujui : 28 Juli 2019 / Dipublikasikan : 7 Agustus 2019 \\ CDepartment of Crop Science, Padjadjaran University
}

\begin{abstract}
Many chili farmers use chemical pesticides as the main choice for controlling curly diseases. This study aimed to redundant the potential of leaves extracts: four o'clock flower and pagodas, in controlling chili disease caused by viruses. This research was carried out in the endemic area of curly disease in red chili, Sukoharjo Districts. This research was carried out from April to June 2018. The material used plants as organic pesticides: leaves of four o'clock flowers and pagodas. Tools are used: blenders, sprayers, jerry cans, basins and stationery. The study used a Randomized Block Design (RBD) with five treatments of leaf extracts application. There were without organic pesticides application, leaves of four o'clock flower with concentration $50 \mathrm{~mL} / \mathrm{L}$; leaves of four o'clock flower with concentration 100 $\mathrm{mL} / \mathrm{L}$; leaves of pagoda flower with concentration $50 \mathrm{~mL} / \mathrm{L}$; and leaves of pagoda flower with concentration $100 \mathrm{~mL} / \mathrm{L}$. Each treatment plot replicated three times. The results showed that leaves extract of four o'clock flower and pagoda gave lower disease incidence and disease severity than without organic pesticide, so yield of plants are higher. the best yield, about $255 \mathrm{~g}$, is given by leaf extract of four o'clock flower at the dose of $100 \mathrm{~mL} / \mathrm{L}$.
\end{abstract}

Keywords: Cayenne pepper · Four o'clock flower $\cdot$ Pagoda $\cdot$ Leaf extract

Sari. Banyak petani cabai yang menggunakan pestisida kimia sebagai pilihan utama untuk mengendalikan penyakit keriting. Penelitian ini bertujuan mempelajari potensi ekstrak

\begin{tabular}{l}
\hline Dikomunikasikan oleh Fitri Widiantini \\
\hline Prabowo, S.M. ${ }^{1} \cdot$ S.A. Dewi ${ }^{1}$ \\
${ }^{1}$ Prodi Agroteknologi Fakultas Pertanian UNIBA Surakarta \\
Korespondensi :
\end{tabular}

tumbuhan berdaya antivirus: bunga pukul empat dan pagoda, dalam mengendalikan penyakit keriting pada cabai yang disebabkan virus. Penelitian ini dilakukan di lahan endemi penyakit keriting pada cabai merah di daerah Kabupaten Sukoharjo. Penelitian ini dilaksanakan mulai bulan April sampai Juni 2018. Bahan yang digunakan adalah tanaman sebagai bahan pesisida nabati: bunga pukul empat dan pagoda. Alat yang digunakan blender, sprayer, jerigen, baskom dan alat tulis. Penelitian menggunakan rancangan acak kelompok (RAK) dengan 5 perlakuan, yaitu tanpa perlakuan pestisida nabati; ekstrak daun bunga pukul empat konsentrasi $50 \mathrm{~mL} / \mathrm{L}$; ekstrak daun bunga pukul empat konsentrasi $100 \mathrm{~mL} / \mathrm{L}$; ekstrak daun pagoda konsentrasi 50 $\mathrm{mL} / \mathrm{L}$; dan ekstrak daun pagoda konsentrasi 50 $\mathrm{mL} / \mathrm{L}$. Setiap plot perlakuan terdiri dari $3 \mathrm{kali}$ ulangan. Hasil penelitian menunjukkan perlakuan ekstrak daun pukul empat dan pagoda memberikan insidens penyakit dan keparahan penyakit lebih rendah daripada tanpa perlakuan pestisida nabati, sehingga memberikan hasil yang lebih baik. Hasil cabai terbesar, yaitu sebesar $255 \mathrm{~g}$, diperoleh dari perlakuan ekstrak bunga pukul empat dengan konsentrasi $100 \mathrm{~mL} / \mathrm{L}$.

Kata Kunci: Cabai rawit - Bunga pukul empat • Pagoda $\cdot$ Ekstrak daun

\section{Pendahuluan}

Cabai merupakan komoditas sayuran yang cukup strategis, baik cabai merah maupun cabai rawit. Cabai juga digunakan sebagai penyedap 
masakan dan penambah selera makan sehingga masakan tanpa cabai terasa tawar dan hambar.

Pada musim tertentu, kenaikan harga cabai cukup signifikan sehingga mempengaruhi tingkat inflasi. Fluktuasi harga ini terjadi hampir setiap tahun dan meresahkan masyarakat. Upaya pemerintah dalam mengatasi gejolak harga cabai dengan melakukan upaya peningkatan luas tanam cabai pada musim hujan, pengaturan luas tanam dan produksi cabai pada musim kemarau, stabilisasi harga cabai, serta pengembangan kelembagaan kemitraan yang andal dan berkelanjutan.

Rata-rata hasil panen cabai merah pada tahun 2002 tercatat sebesar 1,8 ton/ha (BPS, 2002) dan pada tahun 2003 tercatat 5,3 ton/ha (BPS, 2003). Pada tahun 2015 produksi cabai besar mengalami penurunan sebesar 2,59 persen dibandingkan tahun 2014 (BPS, 2017).

Kebutuhan cabai untuk kota besar yang berpenduduk satu juta atau lebih sekitar 800.000 ton/tahun atau 66.000 ton/bulan. Pada musim hajatan atau hari besar keagamaan, kebutuhan cabai biasanya meningkat sekitar $10-20 \%$ dari kebutuhan normal. Tingkat produktivitas cabai secara nasional selama 5 tahun terakhir sekitar 6 ton/ha. Kebutuhan bulanan masyarakat perkotaan memerlukan luas panen cabai sekitar 11.000 ha/bulan, sedangkan pada musim hajatan luas area panen cabai yang harus tersedia berkisar antara 12.100-13.300 ha/bulan. Kebutuhan cabai tersebut belum termasuk untuk konsumsi harian masyarakat pedesaan atau kota-kota kecil serta untuk bahan baku olahan (Pusat Data dan Sistem Informasi Pertanian, 2015).

Untung (1993) menegaskan bahwa penggunaan insektisida dapat menimbulkan dampak negatif, antara lain timbulnya resistensi hama, ledakan hama kedua, resurgensi atau peristiwa meningkatnya populasi hama setelah memperoleh perlakuan insektisida, terbunuhnya musuh alami, bahaya bagi kesehatan masyarakat, dan ancaman pencemaran lingkungan.

Banyak kerugian yang didapatkan dari penggunaan pestisida kimia sintetik yang berlebihan. Pemerintah sendiri sudah memberikan penyuluhan melalui kecamatan tentang dampak dari pestisida kimia. Salah satu solusi untuk mengendalikan penyakit yaitu dengan menggunakan pestisida nabati sebagai konsep pertanian organik.
Ketahanan sistemik dari suatu tanaman dapat dipicu oleh agen biologis seperti mikroorganisme nonpatogenik (Oka, 2002), dan bahan organik tertentu (Kessmann, et. al., 1994). Ketahanan sistemik terinduksi dapat juga dipicu/dirangsang oleh ekstrak tumbuhan, seperti Clerodendrum aculeatum (Verma, et. al., 1996). Ekstrak tanaman lainnya seperti daun bayam duri (Amaranthus spinosus), daun bunga pukul empat (Mirabilis jalapa), dan daun bunga pagoda (Clerodendrum paniculatum) dilaporkan dapat menginduksi ketahanan sistemik terhadap patogen antraknosa dan cucumber mosaic virus (CMV) pada cabai (Hersanti, 2003; Suganda, 2000).

Penggunaan ekstrak tanaman sebagai pestisida nabati untuk mengendalikan penyakit yang disebabkan virus khususnya pada cabai belum banyak dikaji, sehingga diperlukan penelitian mengenai hal tersebut. Informasi tentang pestisida nabati dari bahan-bahan tanaman yang menghasilkan senyawa antivirus diharapkan dari penelitian ini.

\section{Bahan dan Metode}

Bahan yang digunakan adalah tanaman sebagai bahan pestisida nabati: bunga pukul empat dan pagoda. Alat yang digunakan adalah blender, sprayer, jerigen, baskom dan alat tulis.

Penelitian ini dilakukan di lahan endemi penyakit keriting pada cabai merah di Desa Joho, Kecamatan Mojolaban, Kabupaten Sukoharjo. Penelitian ini dilaksanakan mulai bulan April sampai Juni 2018. Penelitian menggunakan rancangan acak kelompok (RAK) dengan 5 kombinasi perlakuan, yaitu tanpa perlakuan pestisida nabati; ekstrak daun bunga pukul empat konsentrasi $50 \mathrm{~mL} / \mathrm{L}$; ekstrak daun bunga pukul empat konsentrasi $100 \mathrm{~mL} / \mathrm{L}$; ekstrak daun pagoda konsentrasi $50 \mathrm{~mL} / \mathrm{L}$; dan ekstrak daun pagoda konsentrasi $50 \mathrm{~mL} / \mathrm{L}$. setiap plot perlakuan terdiri dari 6 tanaman dan 3 kali ulangan, sehingga total terdapat 90 tanaman. Tata laksana penelitian meliputi: survei lahan, persiapan lahan, penyiapan beberapa tanaman sebagai bahan pestisida nabati, pembuatan pestisida nabati, dan aplikasi perlakuan.

\section{Variabel yang diamati :}


Insidens Penyakit. Insidens penyakit merupakan persentase dari jumlah daun sakit. Satuan pengamatan merupakan jumlah daun total dari satu tanaman. Pengamatan dilakukan seminggu satu kali hingga panen.

$$
\mathrm{IP}=\frac{a}{b} \times 100 \%
$$

Keterangan:

IP merupakan Insidens Penyakit (\%), a (Jumlah daun sakit), b (Jumlah daun total).

Keparahan Penyakit. Pengamatan keparahan penyakit dilakukan pada minggu terakhir pengamatan. Metode yang digunakan adalah skoring. Nilai skoring yang dijadikan sebagai acuan adalah 0 (tidak ada serangan), 1 (0 $\leq x \leq 20 \%$ bagian daun yang terserang), $2(20 \leq x$ $\leq 40 \%$ bagian daun yang terserang), $3(40 \leq x \leq$ $60 \%$ bagian daun yang terserang), $4(60 \leq x \leq 80 \%$ bagian daun yang terserang), dan 5 (80 $\leq x \leq$ $100 \%$ bagian daun yang terserang).

Tinggi Tanaman. Tinggi tanaman diamati dengan mengukur tinggi dari pangkal batang hingga titik tumbuh tanaman. Tinggi tanaman diukur sejak 3 hingga 10 MST.

Hasil Cabai. Data pengamatan diperoleh dengan cara menimbang hasil cabai setiap tanaman .
Data hasil penelitian dianalisis dengan menggunakan uji $F$ taraf $5 \%$ dan uji DMRT (Duncan's Multiple Range Test) taraf 5\%. Pengamatan variabel meliputi insidens penyakit (\%), keparahan penyakit (\%), tinggi tanaman, dan hasil cabai.

\section{Hasil dan Pembahasan}

Insidens Penyakit. Hasil penelitian ini menunjukkan bahwa aplikasi ekstrak bunga pukul empat dan pagoda mampu menekan kejadian penyakit keriting pada cabai. Hal ini terlihat dari hasil pengamatan yang disajikan pada Gambar 1 bahwa nilai insidens penyakit pada perlakuan tanpa aplikasi pestisida nabati lebih tinggi daripada berbagai ekstrak bunga pukul empat dan pagoda. Nilai insidens penyakit di akhir pengamatan pada 10 MST yang paling tinggi sampai yang paling rendah berturut-turut adalah tanpa perlakuan $=63 \%$; bunga pukul empat konsentrasi $100 \mathrm{~mL} / \mathrm{L}=$ 40\%; pagoda konsentrasi $100 \mathrm{~mL} / \mathrm{L}=39 \%$; pagoda konsentrasi $50 \mathrm{~mL} / \mathrm{L}=33 \%$; bunga pukul empat konsentrasi $50 \mathrm{~mL} / \mathrm{L}=29 \%$.
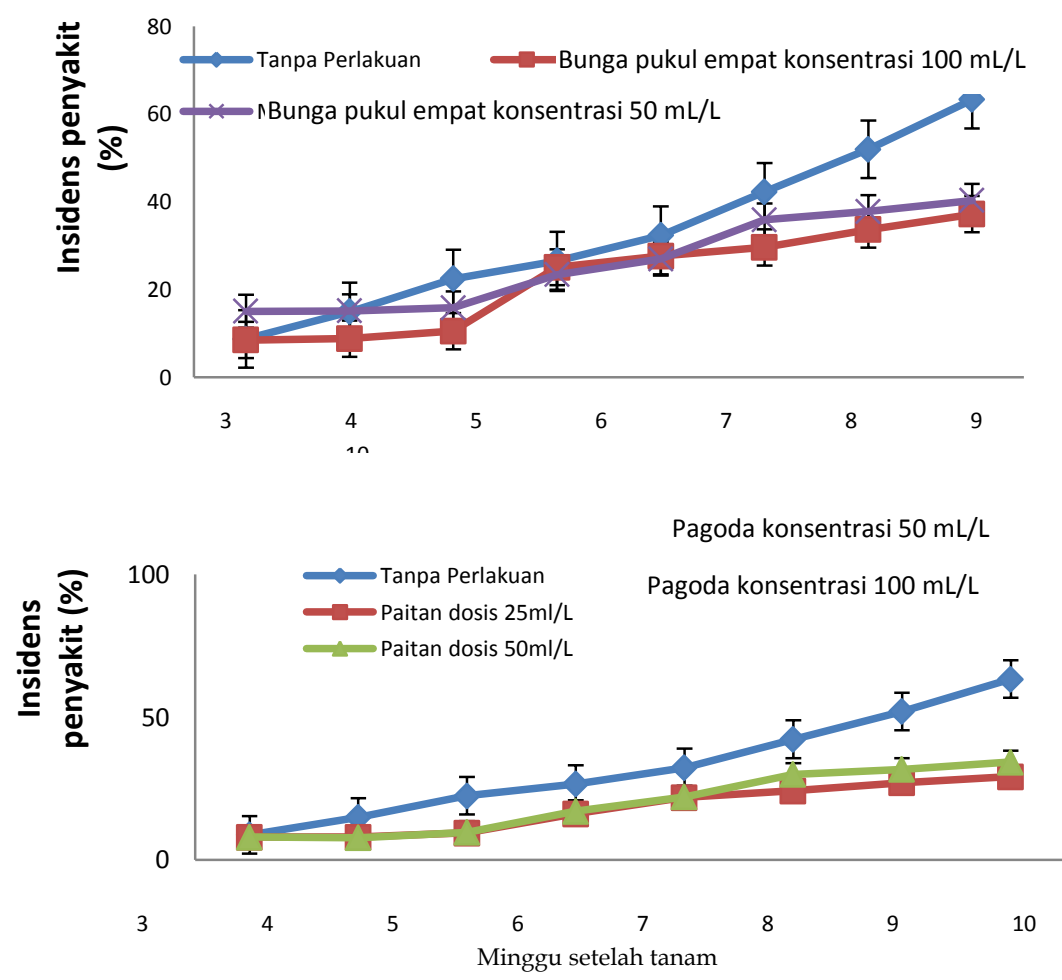

Gambar 1. Insidens penyakit keriting (\%) pada tanaman cabai yang diperlakukan dengan ekstrak daun bunga pukul empat (grafik atas) dan ekstrak pagoda (grafik bawah). 
Tanpa perlakuan memiliki nilai insidens penyakit yang paling tinggi dibandingkan ekstrak bunga pukul empat dan pagoda. Dengan demikian dapat disimpulkan bahwa pemberian ekstrak bunga pukul empat dan pagoda berpengaruh terhadap insidens penyakit jika dibandingkan dengan tanpa perlakuan. analisis uji DMRT menunjukkan beda nyata antara tanpa perlakuan dengan ekstrak bunga pukul empat dan pagoda.

Penelitian ini menunjukkan bahwa ekstrak daun bunga pukul empat dan pagoda diduga kuat mengandung senyawa antivirus yang berfungsi dapat menekan perkembangan virus penyebab penyakit keriting. Penelitian yang dilakukan oleh Jassim \& Naji (2003) menyatakan bahwa ada tiga tahap mekanisme senyawa antivirus yaitu pertama, mengikat protein selubung protein virus. Kedua, dengan cara berikatan dengan virus dan atau protein dari membaran sel inang, sehingga menahan absorbsi virus ke dalam sel. Ketiga, menginaktifkan virus secara langsung dan atau menghambat virus masuk ke dalam sel.

Senyawa antivirus terkandung pada beberapa macam tanaman. Hal ini telah dibuktikan oleh Rahardjo et al., (2004) yang menyatakan bahwa ekstrak mimba mampu menghambat intensitas serangan tobacco mosaic virus (TMV). Lebih lanjut lagi oleh Somowiyarjo et al., (2001) yang menyatakan bahwa ekstrak daun bunga pukul empat dapat menghambat infeksi virus CMV pada Chenopodium amaranticolor. Kemudian diperkuat oleh Kardinan (2006) yang menyatakan bahwa Mimba mengandung nimbin dan nimbidin yang berperan sebagai antivirus yang sangat bermanfaat dalam mengendalikan penyakit tanaman.

Keparahan Penyakit. Gambar 2 menunjukkan bahwa tanpa perlakuan pestisida nabati memiliki tingkat keparahan penyakit yang paling tinggi yaitu sebesar $79 \%$, sedangkan perlakuan yang lain menunjukkan tingkat keparahan penyakit yang relatif lebih rendah, yaitu bunga pukul empat konsentrasi $50 \mathrm{~mL} / \mathrm{L}$ sebesar $35 \%$; bunga pukul empat konsentrasi $100 \mathrm{~mL} / \mathrm{L}$ sebesar $31 \%$; pagoda konsentrasi 50 $\mathrm{mL} / \mathrm{L}$ sebesar $33 \%$; pagoda konsentrasi 100 $\mathrm{mL} / \mathrm{L}$ sebesar $33 \%$. Tingkat keparahan penyakit pada perlakuan ekstrak bunga pukul empat dan pagoda dibawah $50 \%$ yang artinya perlakuan yang diberikan mampu menekan keparahan penyakit hingga $50 \%$, sedangkan tingkat keparahan penyakit pada tanpa perlakuan pestisida nabati diatas $50 \%$ yang artinya bahwa tanpa perlakuan pestisida nabati menunjukkan tingkat keparahan penyakit yang lebih besar daripada perlakuan ekstrak tanaman antivirus.

Hasil pengamatan yang disajikan pada Gambar 2 bahwa nilai keparahan penyakit pada tanpa perlakuan pestisida nabati lebih tinggi daripada berbagai ekstrak bunga pukul empat dan pagoda. Dengan demikian dapat disimpulkan bahwa pemberian ekstrak bunga pukul empat dan pagoda berpengaruh terhadap keparahan penyakit. Analisis uji DMRT menunjukkan beda nyata antara tanpa perlakuan pestisida nabati dengan ekstrak bunga pukul empat dan pagoda.

Menurunnya insidens dan keparahan penyakit akibat ekstrak bunga pukul empat dan pagoda diduga karena mengandung senyawa antivirus, selain itu bisa jadi karena meningkatnya ketahanan tanaman cabai atau disebut juga ketahanan sistemik terinduksi. Menurut Maule, et. al., (2007) menyatakan bahwa ketahanan sistemik terinduksi dikategorikan sebagai perlindungan secara biologi pada tanaman dimana tanaman adalah targetnya bukan patogennya.

Ketahanan sistemik dari suatu tanaman dapat diaktifkan dengan menginduksi gen-gen ketahanan yang terdapat di dalam tanaman dengan memanfaatkan agens penginduksi ketahanan (Kuc, 1987). Hal yang sama dilaporkan oleh Vivek, et. al., (1995) bahwa Clerodendrum inerme dapat menginduksi ketahanan sistemik tanaman tembakau terhadap TMV (Tobacco Mosaic Virus). Lebih lanjut lagi penelitian yang dilakukan oleh Kumalasari, Martosudiro, \& Hadiastono (2015) menyatakan bahwa ekstrak $M$. Jalapa memiliki sifat inhibitor terkuat dibandingkan dengan ekstrak $E$. crassipes, E. alvarezii dan A. spinosus

Goldbach, et. al., (2003) menyatakan bahwa asam salisilat memegang peranan penting dalam ketahanan sistemik terinduksi, asam salisilat ini terbentuk pada tanaman sebagai reaksi terhadap infeksi pathogen. Lebih lanjut lagi menurut Murphy et al., (2000) Asam salisilat akan mengaktifkan ketahanan tanaman terhadap penyakit. Terinduksinya ketahanan tanaman cabai akibat ekstrak daun bunga pukul emapat dan pagoda diduga disebabkan oleh semakin meningkatnya kandungan asam salisilat. 


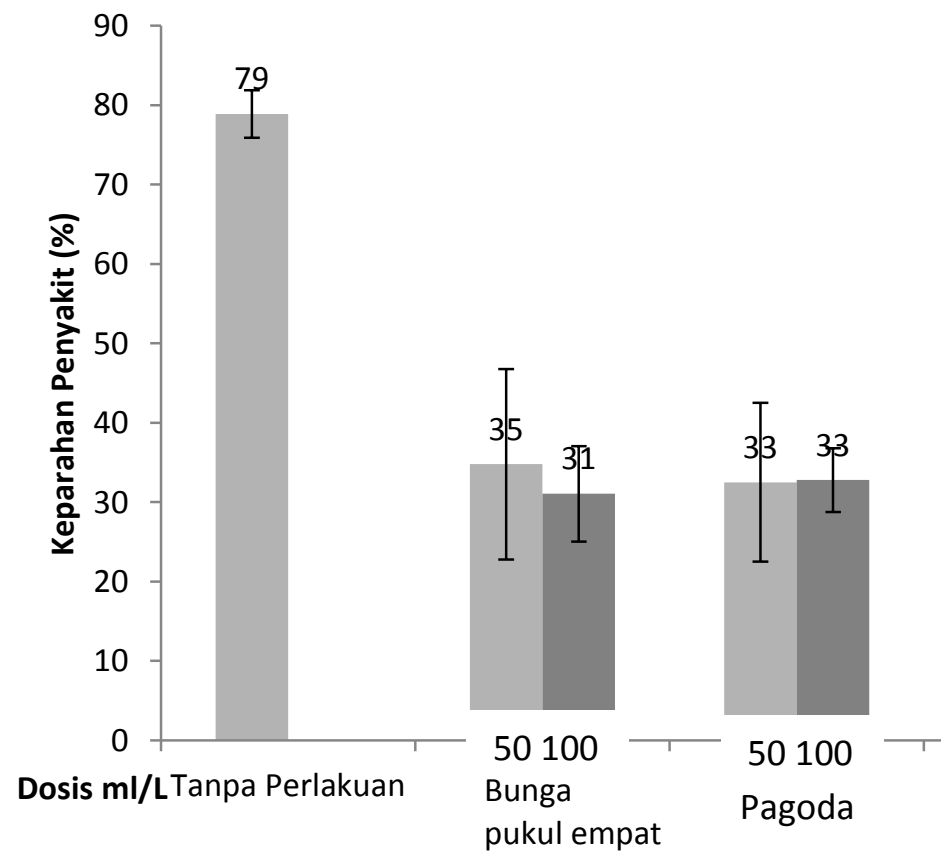

Gambar 2. Pengaruh ekstrak daun bunga pukul empat dan daun pagoda terhadap keparahan penyakit.
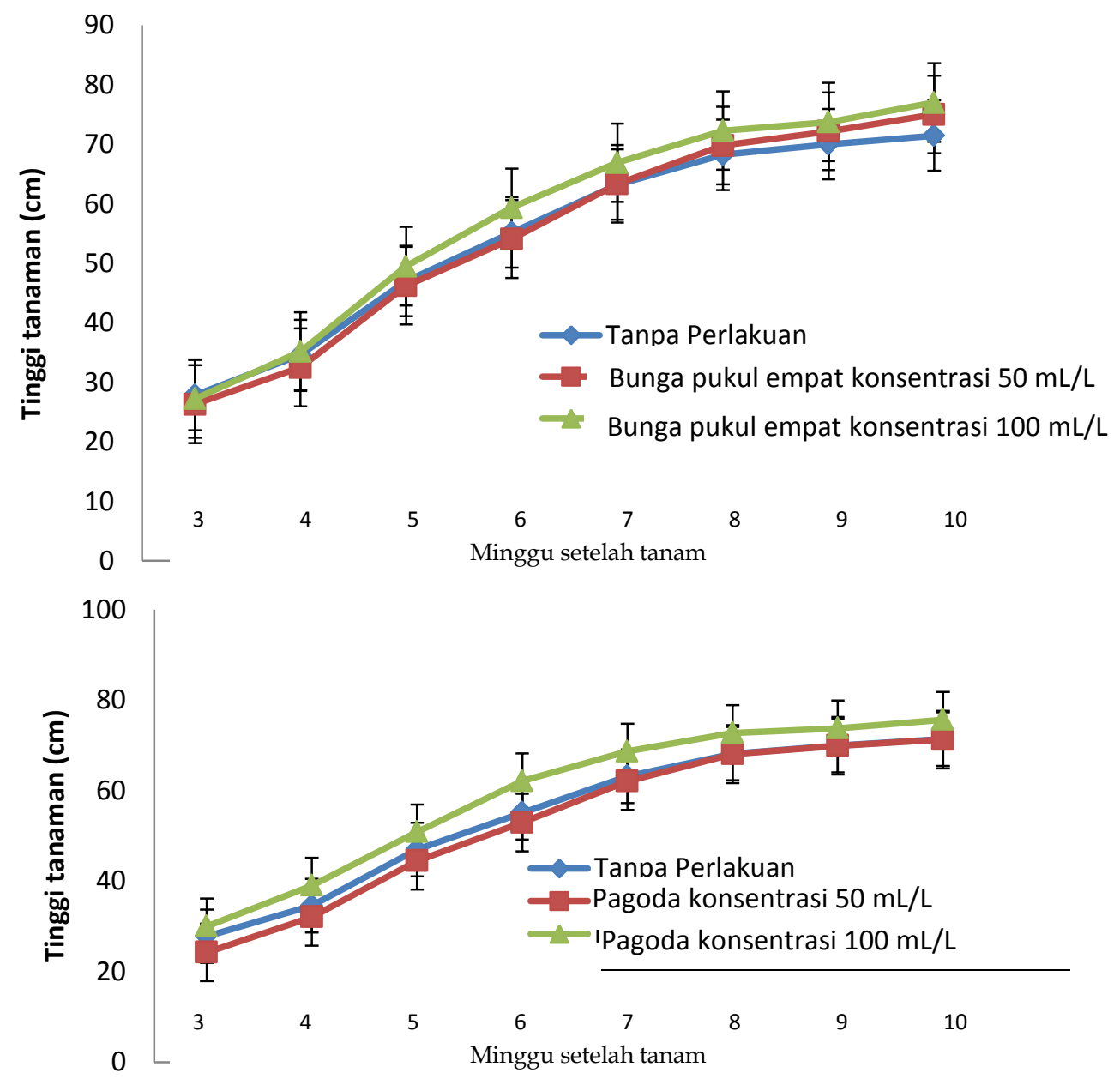

Gambar 3. Pengaruh ek strak daun bunga pukul empat dan daun pagoda terhadap pertumbuhan tinggi tanaman cabai. 
Tinggi Tanaman. Tinggi tanaman merupakan ukuran tanaman yang sering diamati, baik sebagai indikator pertumbuhan maupun sebagai parameter yang digunakan untuk mengetahui pengaruh lingkungan atau perlakuan yang diterapkan. Hal ini disebabkan karena tinggi tanaman merupakan ukuran pertumbuhan yang paling mudah diamati.

Hasil pengamatan disajikan pada Gambar 3 menunjukkan bahwa rerata tinggi tanaman dari setiap perlakuan ekstrak antivirus nabati menyebabkan tinggi tanaman tidak berbeda dari tanpa perlakuan pestisida nabati. Uji DMRT menunjukkan bahwa tidak adanya perbedaan yang nyata terhadap perlakuan yang diberikan.

Duriat (2008) menyatakan bahwa gejala lanjut dari penyakit keriting dapat menyebabkan pertumbuhan tidak normal dan akhirnya tanaman menjadi kerdil. Gejala lanjut tersebut tidak terjadi pada tanaman yang diinduksi oleh ekstrak bunga pukul empat dan pagoda. Hal ini karena pengaruh dari ekstrak tumbuhan yang mampu menekan perkembangan penyakit keriting sehingga pertumbuhan tanaman relatif normal.Pada penelitian ini, tinggi tanaman tidak dipengaruhi oleh insidens penyakit. Perlu pengamatan komponen pertumbuhan tanaman yang lain agar dapat diketahui gangguan penyakit terhadap pertumbuhan.

Hasil Cabai. Cabai yang menunjukkan gejala penyakit keriting hingga tanaman menjadi kerdil akan mengalami penurunan hasil cabai bahkan jika sudah sangat parah tidak mampu menghasilkan buah. Hal ini disebabkan karena rontoknya bunga cabai pada saat sebelum mekar atau sebelum mengalami penyerbukan.

Hasil pengamatan yang disajikan pada Gambar 4 bahwa hasil cabai pada tanpa perlakuan pestisida nabati lebih rendah daripada berbagai ekstrak bunga pukul empat dan pagoda. Gambar 4 terlihat bahwa tanpa perlakuan pestisida nabati yang paling rendah hasil cabainya yaitu 96 gram, hal ini terjadi karena disebabkan oleh penyakit keriting yang tingkat keparahan penyakitnya cukup tinggi, sedangkan pada perlakuan ekstrak tanaman antivirus hasil cabainya relatif sama tetapi lebih tinggi daripada tanpa perlakuan pestisida nabati, hasil cabai paling tinggi pada perlakuan bunga pukul empat konsentrasi 100 mL/L yaitu sebesar 255 gram.

Data hasil cabai dalam satuan jumlah buah per 6 tanaman sampel, umumnya menunjukkan bahwa semua ekstrak tanaman antivirus lebih baik dari tanpa perlakuan pestisida nabati. Analisis uji DMRT menunjukkan beda nyata antara tanpa perlakuan pestisida nabati dengan ekstrak bunga pukul empat dan pagoda.

Penyakit keriting ini pada beberapa varietas cabai cukup merugikan, hasil panen berkurang sampai terjadi puso, terutama pada tanaman yang sudah terinfeksi sejak masa tanaman masih sangat muda. Kerugian petani akibat penyakit ini secara keseluruhan dapat mencapai milyaran rupiah. Pada tanaman cabai rawit yang terserang sampai $100 \%$ masih mampu menghasilkan buah walaupun hanya sedikit, sedangkan pada cabai besar sering hanya menghasilkan kurang dari 5 buah saja (Duriat, 2009).

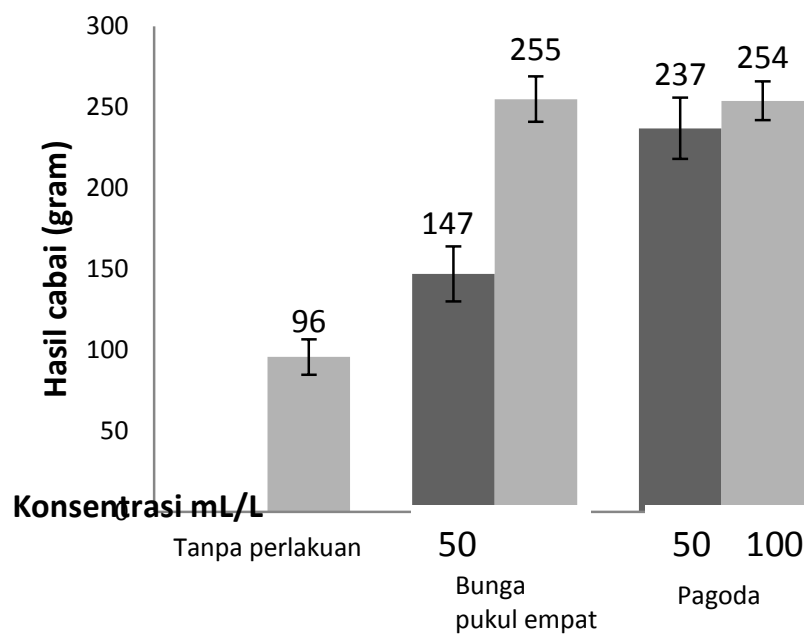

Gambar 4. Diagram Hubungan antara ekstrak daun bunga pukul empat dan daun pagoda dengan hasil Cabai. 
Penelitian ini diharapkan bisa memberikan informasi tentang alternatif pengendalian penyakit keriting yang lebih ramah lingkungan sehingga mampu mempertahankan atau bahkan meningkatkan hasil cabai. Menurut Syamsidi et al., (1997) Terjadinya infeksi virus pada tanaman cabai dapat menurunkan pertumbuhan dan hasil tanaman, baik secara kuantitatif maupun kualitatif.

Hasil pengamatan dari hasil cabai sesuai dengan pengamatan terhadap insidens penyakit dan keparahan penyakit bahwa ekstrak bunga pukul empat dan pagoda mampu menekan perkembangan penyakit keriting sehingga hasil cabai lebih tinggi daripada tanpa perlakuan. Adanya keselarasan antara daya hambat dari ekstrak bunga pukul empat dan pagoda terhadap perkembangan virus keriting sehingga hasil cabai lebih tinggi daripada yang tidak diberi ekstrak tanaman antivirus.

\section{Kesimpulan dan Saran}

\section{Kesimpulan}

1. Ekstrak bunga pukul empat dan pagoda mampu menekan insidens dan keparahan penyakit keriting sehingga hasil cabai lebih tinggi daripada tanpa perlakuan.

2. Hasil pengamatan menunjukkan bahwa Insidens penyakit pada perlakuan ekstrak bunga pukul empat konsentrasi $50 \mathrm{~mL} / \mathrm{L}$ mempunyai nilai terendah yaitu $29 \%$, keparahan penyakit pada ekstrak bunga pukul empat konsentrasi $100 \mathrm{~mL} / \mathrm{L}$ mencapai nilai terendah yaitu $31 \%$, hasil cabai tertinggi diperoleh dari perlakuan ekstrak bunga pukul empat konsentrasi 100 $\mathrm{mL} / \mathrm{L}$ yaitu sebesar $255 \mathrm{~g}$.

Saran. opPerlu penelitian lebih lanjut lagi tentang konsentrasi yang efektif dari ekstrak bunga pukul empat dan pagoda.

\section{Daftar Pustaka}

BPS. (2002). Produksi Tanaman Sayuran dan Buahbuahan. Jakarta: Badan Pusat Statistik.

BPS. (2003). Produksi Tanaman Sayuran dan Buahbuahan. Jakarta: Badan Pusat Statistik.

BPS. (2017). Statistik Tanaman Sayuran dan Buahbuahan. Jakarta: Badan Pusat Statistik.

Duriat, A. S. (2008). Pengaruh Ekstrak Bahan
Nabati dalam Menginduksi Ketahanan Tanaman Cabai terhadap Vektor dan Penyakit Kuning Keriting. J Hort, 18(4), 446-456.

Duriat, A. S. (2009). No TitlePengendalian Penyakit Kuning Keriting pada Cabai (5th ed.). Balai tanaman sayuran.

Goldbach, R., Bucher, E., \& Prins, M. (2003). Resistance mechanisms to plant viruses: an overview. Virus Research, 92(2), 207-212. Retrieved from https://doi.org/10.1016/S01681702(02)00353-2

Hersanti. (2003). Pengujian potensi ekstrak 37 spesies tumbuhan sebagai agens penginduksi ketahanan sistemik tanaman cabai merah terhadap Cucumber mosaic virus. Fitopatologi Indonesia, 7(2), 54-58.

Jassim, S. A. A., \& Naji, M. A. (2003). Novel antiviral agents: A medicinal plant perspective. Journal of Applied Microbiology, 95(3), 412-427. https://doi.org/10.1046/j.13652672.2003.02026.x

Kardinan, A. (2006). Manfaat Mimba (Azadirachta indica). Sinar Tani.

Kessmann, H., Staub, T., Hofmann, C., Maetzke, T., Herzog, J., Ward, E., ... Ryals, J. (1994). Induction of systemic acquired disease resistance in plants by chemicals. Annual Review of Phytopathology, 32, 439-459. https://doi.org/https://doi.org/10.1146/a nnurev.py.32.090194.002255

Kuc, J. (1987). Plant Immunization and its applicability for disease control. Di dalam: Chet I, editor. Inovative Approaches to Plant Disease Control.

Kumalasari, R. N., Martosudiro, M., \& Hadiastono, T. (2015). Pengaruh berbagai jenis ekstrak nabati terhadap infeksi Cucumber Mosaic Virus (CMV) pada tanaman mentimun (Cucumis satious L.). Jurnal HPT, 3(1), 30-34.

Maule, A. J., Caranta, C., \& Boulton, M. I. (2007). Sources of natural resistance to plant viruses: status and prospects. Molecular Plant Pathology, 8(2), 223-231. https://doi.org/10.1111/j.13643703.2007.00386.x

Murphy, A. M., Gilliland, A., Wong, C. E., West, J., Singh, D. P., \& Carr, J. P. (2000). Signal transduction in resistance to plant viruses. European Journal of Plant Pathology, 107, 121128. $\quad$ Retrieved from 
https://link.springer.com/article/10.1023/ A:1008732123834

Oka, I. (2002). Ketahanan sistemik terinduksi tanaman cabai merah (Capsicum annuum L.) terhadap Cercospora capsici Heald \& Wolf, Fusarium oxysporum Schlecht. f.sp vasinvectum Snyder \& Hans., dan Colletotrichum gloeosporiodes (Penz.) Sacc. dengan penginokulasian Rhizopseu. Jurnal Hama Penyakit Tumbuhan, 95(9), 8089.

Pusat Data dan Sistem Informasi Pertanian. (2015). Outlook: Komoditas Pertanian Sub sektor Hortikultura Cabai. Retrieved from http:/ / epublikasi.setjen.pertanian.go.id/.

Rahardjo, I. B., Sulyo, Y., \& Maryam, A. (2004). Pengaruh ekstrak Mimba secara mekanis terhadap virus mosaic tembakau strain Aggrek (TMV-O) pada tanaman indikator Tembakau. Jurnal Hortikultura, 4(5), 94-98.

Somowiyarjo, S Sumardiyono, Y., \& Martono. (2001). Inaktivasi CMV dengan ekstrak Mirabilis jalapa. Prosiding Kongres Nasional XVI Dan Seminar Ilmiah, PFI, 218-220.
Bogor.

Suganda, T. (2000). Introduction of resistance of red pepper against fruit antracnose by the application of biotic and abiotic inducers. $J$ Agrikultura, 11, 72-78.

Syamsidi, S., Hasdiatono, T., \& Putra, S. (1997). Ketahanan cabai merah terhadap Cucumber Mosaic Virus (CMV) pada umur tanaman pada saat inokulasi. Prosiding Kongres Nasional XIV Dan Seminar Ilmiah. Perhimpunan Fitopalogi Indonesia.

Untung, K. (1993). Pengantar Pengelolaan Hama Terpadu. Yogyakarta: Gajah Mada University press.

Verma, H., Srivastrava, S., Varsha, \& Kumar, D. (1996). Induction of systemic resistance in plants against viruses by basic protein from Clerodendrum aculeatum leaves. Phytopathology, 86, 485-492.

Vivek, P., Shalini, S., Varsha, H., \& Verma. (1995). Two basic protein isolated from Clerodendrum inerme are inducer of systemic antivirus resistance in susceptible plants. Plant Science, 110, 73-82. 